\title{
The Quest for a Quality Delivery of University Education in Malawi
}

\author{
Lester Brian Shawa \\ Lecturer in Higher Education, Higher Education Training and Development, \\ University of KwaZulu Natal, South Africa \\ shawa@ukzn.ac.za
}

\section{Doi:10.5901/mjss.2014.v5n20p1176}

\begin{abstract}
Studies in higher education show that a quality delivery of university education is paramount for the development of countries. However, achieving a quality delivery of university education is a serious endeavour in most African countries such as in Malawi. In this article, I explain the challenges faced by the university sector in Malawi and propose four complementary tenets necessary for achieving a quality delivery of university education. The four proposed tenets hinge on a need for: a coordinated higher education policy framework, an elaborate university education financing mechanism, a robust quality assurance system and a deliberative democratic governance university system. This paper contributes to debates and discourses surrounding efforts to achieve quality and relevance of university education in Africa and beyond.
\end{abstract}

Keywords: quality delivery of university education, policy framework, financing mechanism, quality assurance, deliberative democratic governance

\section{Introduction}

Malawi has three national public universities: the University of Malawi establishment in 1965, Mzuzu University established in 1997 and the newly established Malawi University of Science and Technology (2014). There are a few private universities that include the Catholic University of Malawi established in 2006, the University of Livingstonia (a presbeterian university) established in 2003,and the recent ones that include the Blantyre International University,the Exploits University the Adventist University.

Universities in Malawi face several challenges that eventually affect the delivery of quality university education. Drawing on long-term strategies, such as the Vision 2020 document (Malawi Government, 2000a), the Policy and Investment Framework has outlined major policies and strategies for higher education to improve the sector (Malawi Government, 2000b). Subsequently, the National Education Sector Plan (NESP) (Malawi Government, 2006a) draws on Vision 2020, the Policy and Investment Framework and the Malawi Growth and Development Strategy (MGDS) (Malawi Government, 2006b) to explain different government strategies to face the challenges. As outlined in the policy documents the challenges mainly include: limited university access, lack of relevance, poor management, lack of teaching and research capacity and lack of quality (Malawi Government 2000b).Important to note however that these challenges are not typical to Malawi as Saint (1992:7) posits:

\begin{abstract}
...to varying degrees, the universities of sub-Saharan Africa face four common problems: enrolments are often increasing faster than the capacity of universities to plan for and accommodate them, current patterns of higher education expenditure are unsustainable suggesting that the model of publicly supported residential universities is inequitable and financially inefficient, declining of education quality as a result of increased enrolments and/or reduced funding and a growing concern of the relevance of universities to national needs for both government and citizens.
\end{abstract}

In this paper, I propose four tenets for achieving quality university education in Malawi. Before offering my proposals, I briefly discuss the context and challenges of the university sector faced by the country.

\section{Context and Challenges of the University Sector in Malawi}

The establishment of the University of Malawi in 1965 was vital for the production of human resources to replace the colonial personnel in the civil service, which then could, hopefully, contribute to the development of the country. However access to university education remains skewed with less than $0.5 \%$ of the population aged 18 to 23 attending tertiary 
education in recent years (Malawi Government, 2009). This means that both public and private universities that have been newly built have not increased access substantially. This is worrying given the heightened need for university education in the country.

Regrettably the World Bank and its partner organisations have for years placed great emphasis on basic education (Bloom, Canning \& Chan, 2006:11). For Malawi the shift towards basic education by the World Bank has had adverse implications for the Ministry of Education and Vocational Training. With the insistence on basic education, the ministry lacked proper planning mechanisms envisaged for the delivery of quality higher education as it emphasised free primary education at the expense of higher education.

Hall and Thomas (2005:77) argue that the existing links between the higher education community and employers in Malawi are weak. They point out that there is evidence that higher education is not providing the quality of graduate that is necessary to meet the needs of a nation. In addition, they argue that at undergraduate level, curriculum development has not kept pace with changes in the environment and the demands now placed upon graduates. They note that the employment trend has now changed from an emphasis on public to private sector and that there is clear evidence that undergraduate programmes have failed to adapt to this change. Furthermore, they argue that recognition by employers of academic qualifications gained during higher education does not match graduates' expectations. They posit that what is lacking in Malawi are the mechanisms through which a variety of stakeholders, including employers, can arrive at or seek shared understandings about the proper and appropriate role of higher education (Hall \& Thomas, 2005:77).

Showing a quest to contribute to quality university system, the mission statement of the University of Malawi states "to advance knowledge, promote wisdom and understanding and provide services by engaging in teaching and research and by facilitating the dissemination, promotion, and preservation of learning responsive to the needs of Malawi and the world" (University of Malawi, 2012:2). Similarly, the Mzuzu University mission statement also shows an interest in advancing quality and relevance when stating, " the university is to provide quality education, training, research and complementary services to meet the technological, social and economic needs of individuals and communities in Malawi" (Mzuzu University, 2005:9). Although the universities in Malawi show a willingness to achieving quality and relevant education, Chimombo (2003:414) argues that given the 1997 labour survey conducted by the Government of Malawi indicating that $70 \%$ of doctors, $50 \%$ of surveyors of standard, $33 \%$ of architects, $31.5 \%$ of accountants, $23 \%$ of engineers and $22 \%$ of farm managers were not Malawian, it is clear that the country is producing a small percentage of human resources of university-level quality or standard.

The other teething challenge that affects the delivery of a quality university education in Malawi hinges on funding. Public universities in Malawi are autonomous institutions subsidised by the government under a separate budget, independent of the Ministry of Education and Vocational Training but reporting to it (Hayward \& Ncayiyana 2006:3). Thus, the major funding for Malawian public universities is the government. Although the Malawi Government spends more money to the university sector compared to other countries in the region since the public unit cost of university education in Malawi is the highest in the world in terms of GDP per capita, the amount of funding from government does not suffice (Dunga, 2013:191). While funding is crucial, most of the time universities do not get the required amounts for their operations (Hayward \& Ncayiyana 2006). For example, Chancellor College, a constituent of the University of Malawi had an estimated budget of 2,807,393,654 Malawi Kwacha but only received 1,799,103,592 Malawi Kwacha for the year 2010-2011 (Dunga, 2013: 192).

The other challenge that contributes to poor quality education in Malawi is that universities have generally operated without robust defensible education policy frameworks to regulate such things as quality assurance, program accreditation and implementation and institutional accreditation (Hayward \& Ncayiyana, 2006:5).

The concerns afore-mentioned prompted the Malawian government to organise a national education conference from 29 March to 1 April 2005 to rethink policies, strategies and best educational practices for the $21^{\text {st }}$ century. Most papers presented explicitly or implicitly centred on the decline of the quality of education in Malawi in general. However, I contend that there has been no serious follow up of the questions raised during the conference and although the government has just set up the National Council on Higher Education (2014) a lot of work needs to be done. I contend that while the foregoing problems are daunting, with proper mechanisms, they can be lessened in an effort to improve the quality of university education. In the next discussion I offer proposals for achieving a quality delivery of university education in Malawi.

\section{Tenets for Achieving Quality University Education in Malawi}

The conceptualisations of the notion of quality in education have been extensively discussed in literature (see Harvey \& 
Green, 1992; Green, 1994; Shawa, 2008). I don't intend to rehearse the conceptualisations here, but suffice to posit that it is important for universities to try to delineate their understanding of the notion as this determines how much they invest into their teaching, learning and research. In this section I propose four tenets for achieving quality in university education in Malawi that ought to complement each other: (1) developing a coordinated higher education policy framework (2) developing elaborate funding mechanisms (3) developing robust quality assurance mechanisms and (4) developing a deliberative governance university system.

\subsection{A coordinated higher education policy framework}

While as from 2014, the Malawi Government has established the Council on Higher Education, there still lacks a coordinated system that can deliver a quality university education. A lack of policy has created a gap between the higher education institutions and the Ministry of Education and Vocational Training that stifles policy decisions at different educational levels. Thus, there requires changes in attitudes, knowledge levels and expertise in conforming to the new order on the part of university managers, government officials responsible for higher education, academics as well as students.

One pertinent aspect for a coordinated system is the development of a National Qualifications Framework. However, currently in Malawi, public universities have developed their own qualifications frameworks. In a coordinated system, this is counter-productive as the system ought to be national and be used to aid articulation and mobility of students. Thus, while the recent establishment of the National Council on Education in Malawi is important, it does not yet suffice in achieving a coordinated higher education system that could contribute to a quality delivery of university education.

What would be desirable is to position the National Council on Higher Education as an independent statutory body that would comply with the Malawian Qualifications Act and would be endowed with powers to provide advice to the Ministry of Education and Vocational Training. The Council would then have two committees: one to monitor and evaluate policy achievements in higher education and the other to establish and promote quality assurance, audit the quality assurance mechanism and accredit higher education programmes.

More so, there is a need for quality mechanisms to filter through to institutions in a coordinated manner. The challenge however remains the isolated manner under which institutions operate in the absence of a coordinated system. For example, while some individual public universities such as Mzuzu University have established posts for quality officers or directors, the job of these officers is not only misunderstood by their colleagues and the university at large but also it lacks support from university acts and statutes. It seems then that there is also a need to revisit institutional policy instruments before accommodating such officers.

\subsection{An elaborate university education financing mechanism}

Public universities in Malawi are funded or subvented by the government (Malawi Government, 2009). University funding is under a separate budget, independent of the Ministry of Education and Vocational Training, although universities report to this ministry (Hayward \& Ncayiyana, 2006). Funding has proved to be unpredictable and without proper mechanisms (Hayward \& Ncayiyana, 2006). As of 2008, among its neighbours, Malawi had the lowest GDP per capita at USD 257 in comparison to Mozambique (USD 397), Zambia (USD 898) and Tanzania (USD 363) (IMF World Economic Outlook Database, 2008.). However, Malawi spends relatively more per capita on university education than some neighbouring countries (Sayed, Mackenzie, Shall, \& Ward, 2008). As noted, funding is crucial and most of the time universities do not get the required amounts for their operations. Universities are expected to source for more resources on their own, which presents a very big challenge in running universities in Malawi.

A cost-sharing mechanism for universities was ushered in 2001 (Dunga, 2013) but it received serious resistance from the university student unions. However, by 2006, the Malawi Government approved student fees of 25000 Kwacha (US\$ 170) per annum at the University of Malawi and 55000 Kwacha (US\$ 390) at Mzuzu University (Hayward \& Ncayiyana, 2006). However by the same year, non- residential students paid 100, 000 Kwacha (US\$ 689) at the University of Malawi and 150, 000 Kwacha (US\$1 034) at Mzuzu University respectively.

While a cost-sharing mechanism is a welcome aspect of the university sector in Malawi, its implementation has serious flaws. The first flaw is that students are offered loans to pay for the stipulated fees and up-to-date, there are no clear mechanisms for payback (Shawa, 2007; Dunga, 2013). While the loan scheme is now administered through the bank system, there are numerous systemic challenges to follow up on who owe the government. The second flaw is that the university as well as the government have failed to discern who are supposed to get government scholarship and who 
are supposed to pay on their own (in other words to differentiate between the rich and the poor) so almost everybody qualifies for loans. What is problematic however, is that in Malawi access to the university sector benefits more those in higher income brackets which means that the government pays for the education of the rich and the poor remain marginalised (Dunga, 2013).

To establish an elaborate financing system that could contribute to the delivery of a quality university education, I offer the following suggestions. First there is a need for a procedural policy based prompt financing mechanism to the university sector. In this way, hopefully funding could not be unpredictable and could be paid at required times. I argue that this requires a transparent agreed-upon funding policy that ought to be adhered to.

Second, Malawi should consider putting to a stop the practice of making state presidents automatic university chancellors as this entangles university financing within the politics of the day and the situation degenerates into a university financing "system" at the mercy of the presidency (Shawa, 2011). Besides, the system of state presidents assuming the post of university chancellor has compromised academic freedom and institutional autonomy adversely in Malawi (Shawa, 2012, Kerr \& Mapanje, 2008).

Third, a long-term realistic cost-sharing mechanism ought to be discerned. This means that the government ought to realise that currently the system is benefiting the rich at the expense of the poor (and probably more deserving) students. The current access system uses a quota based on district of origin without taking consideration where the candidates are actually residing and studying i.e. whether they are in town/cities where schooling facilities are better or in rural areas where school facilities are poor. This system has been described as discriminatory and is hotly contested in the Malawian higher education system (Shawa, 2012).

A long-term realistic system, would demand positioning the quota selection for university education using the lenses of urban versus rural i.e. students studying in urban or in rural areas without looking at their districts of origin or tribes. This would ensure that the poor populace that studies in rural areas without proper schooling facilities is given a chance for entry in the university sector.

Fourth, while asking the government to increase funding, universities should also increase their resource base and improve financial management. This could be done through increased short courses, research and publications by academics and making sure that only the needy students get government subsidies, among other measures.

\subsection{A robust quality assurance system}

Quality assurance can be defined as "systematic management and assessment procedures adopted to ensure achievement of specified quality and to enable key stakeholders to have confidence in the management of quality and the outcomes achieved" (Harman, 1998:346). Viewed in this way, quality assurance implies a collective process of maintaining the quality of educational process in the university. This exercise calls for a continuous process. Vlasceanu, Grunberg and Parlea (2004:47) argue that as a regulatory mechanism, quality assurance focuses on both accountability and improvement, providing information and judgement (not ranking) through an agreed-on and consistent process and well-established criteria.

Quality assurance embodies several related terms such as quality audit, quality assessment, peer review and accreditation. I briefly explain the terms in turn. Quality audit is "the process of a review of an institution or programme to determine if its curriculum, staff and infrastructure meet its stated aims and objectives" (Hayward, 2006:5). Vlasceanu et al., (2004) contend that quality assessment is a means by which an external body ensures that the institution or programme follows quality assurance procedures or that the overall (internal and external) quality assurance procedures of the system are adequate and are equally being carried out.Thus, quality assessment refers to every structured activity that leads to judgement of the quality of the teaching or learning process and/or research, whether self-assessment or assessment by external experts (see Vroeijenstijn, 1995). Peer review is "one of the pillars of external quality assessment by which a group of experts from outside the higher education institution will assess the faculty" (Vroeijenstijn, 1995:xix) while accreditation is "the process of self-study and external quality review used in higher education to scrutinise colleges, universities and higher education programmes for quality assurance and improvement" (Hayward, 2006:5).

Given that Malawi has finally put together a National Council for Education what is lacking are corresponding mechanisms such as quality assurance models to support the delivery of a quality university education. For the sake of understanding what is happening elsewhere in order to inform practice in Malawi, I present quality assurance models as discussed by Brennan and Shah (2000) and Harman (1998). These European models are useful as guides and hence could be contextualised in Malawi. Brennan and Shah (2000:52) posit that the general model proposed by the European Union and others based on the review undertaken by Van Vught and Vroeijenstijn (1993) has four main elements:

- A national body: This body is endowed with responsibility for coordinating and setting out the procedures and 
methods to be used by institutions of higher education for the assurance of quality. Such a body should, according to the model, have legal status but be independent of the government.

- Institutional self-evaluation: Based on the procedures and methods set up by the national body, institutions should undertake regular self-evaluations and report to the coordinating body regularly.

- External peer evaluation: The institutional self-evaluation would form the basis for external peer evaluation. Such an evaluation should include discussions with academic and administrative staff, students and alumni.

- A published report: This report should set out the findings of the peer review visit and its main purpose should be to make recommendations to institutions in order to help them improve the quality of teaching and research.

Harman (1998:348-349) presents approaches to quality assurance management as follows:

A. Responsible Agency/Unit

(a) National or System Level

- A unit or section within a government agency

- Separate quality assurance agency established by the government

- Separate quality assurance agency established by the government but with considerable independence

- Agency established by a group or association of higher education institutions

- Agency established jointly by the government and higher education institutions

(b) Institutional Level

- Senior university management

- Academic board, academic committee or academic senate

- Specialist committee or board, set up by governing body, senior management or senior academic body

B. Participation in Reviews and other Activities

- Voluntary

- Compulsory

- Voluntary with some measure of pressure

C. Methodologies of Review and Assessment

- Self-study or self-evaluation

- Peer reviews by panels of experts, including the use of at least some external panel members and one or more site visits

- Analysis of statistical information and/or use of performance indicators

- Surveys of students, graduates, employers and professional bodies

- Testing the knowledge, skills and competencies of students

D. Focus

(a) National or System Level

- National reviews of disciplines

- reviews of research only

- reviews of teaching only

- reviews of both teaching and research

- Institutional evaluations

- reviews of teaching only

- reviews of research only

- reviews of quality assurance process

- comprehensive reviews usually including teaching, research, management

- and quality assurance processes

- National evaluations of the higher education system

(b) Institutional Level

- Reviews of departments, faculties and schools

- Reviews of courses and programmes

- Reviews of particular institutional functions or administrative and service units 


\section{E. Purpose}

- Accountability

- Improvement and renewal

- Combination of purposes

\section{F. Reporting and Follow-up Activities}

- Report provided solely to the institution or unit concerned

- Report provided to the institution or unit but also published or made more widely available

- Formal reports provided to the minister, ministry, higher education funding or coordinating agency or at institutional level to the vice-chancellor or rector

- Public reporting

- Use of ranking and wide publication of the results of such ranking

- Performance indicators

- Accreditation or validation

- Improvement and renewal activities

The quality assurance models as discussed by Brennan and Shah (2000) and Harman (1998) posit excellent examples for the Malawi case. I argue for the development of similar models in managing quality assurance in Malawi.

The positive development is that the Council for Higher Education in Malawi is endowed with responsibilities such as advising the minister of higher education, developing policy, developing and recommending a national qualifications framework, accrediting institutions as stipulated in the Malawi Council for Higher Education Act of 2010. However, while the act aims well, I argue that more needs to be done. For example, there is a need of splitting the Ministry of Education into two to create the Ministry of Higher Education to deal with issues solely of the concern of higher education. Currently, The Ministry of Education deals with all aspects of education from early childhood to higher education. Once created, under the Ministry Higher Education, there could be a qualifications authority, which would be an umbrella organisation dealing with all issues pertaining to qualifications including the higher education qualifications. Like in the South African system, this would assist in overseeing the development of the National Qualifications Framework (NQF) and its implementation (South African Government, 2012). The National Qualifications framework would have the responsibility of creating an integrated national framework for learning achievements in Malawi and allow for mobility and articulation of the education system. A quality committee of the national Council for Higher Education could be created to do programme auditing and accreditation.

\subsection{A deliberative democratic governance university system}

I contend that to achieve quality university education in Malawi, elaborate policy frameworks, funding mechanisms and robust quality assurance mechanisms ought to be complemented by a deliberative democratic type of university governance. Although there may be different ways of looking at deliberative democracy, most proponents of deliberative democracy agree that the notion, "includes collective decision making with the participation of all that will be affected or their representatives and also that decision making is by means of arguments offered by and to participants who are committed to values of rationality and impartiality" (Elster, 1999:8). Following on similar understanding, Miller (2000:3) argues that a democratic system is deliberative to the extent that the decisions it reaches reflect open discussion among the participants, with people ready to listen to the views and consider the interests of others, and modify their own opinions accordingly. Gutmann and Thompson (2004: 7) contend:

Values of deliberative democracy require free and equal citizens to justify decisions in a process in which they give one another reasons that are mutually acceptable and generally accessible with the aim of reaching conclusions that are binding in the present but open to challenge in the future (Gutmann \& Thompson, 2004:7).

In the university sector, a need for deliberative mechanisms arises since deliberation aims at promoting the legitimacy of collective decisions, encouraging public spirited perspectives on public issues, promoting mutually respectful purposes of decision making and correcting mistakes that could have arisen in the process of decision making (Gutmann \& Thompson, 2004:10-12). The expectation then is that national policy frameworks ought to be clearly considered following deliberative democratic demands. For Malawi this is important in that it shall arouse interest in people to think of contributing to the higher education sector that has been elitist and marginalised for a long time. A deliberative process for adopting particular funding mechanisms would allow for transparency and accountability in the system and avoid, as earlier noted, universities being at the mercy of the state presidents in receiving funding. For the quest to develop a 
robust quality assurance mechanism, a deliberative democratic mechanism is paramount given the fact that currently these mechanisms are only operating at university/institutional level. To bring about a coordinated quality assurance system, all concerned parties need to deliberate and agree upon the structures from national to institutional levels as outlined in the previous section. In general, a deliberative democratic governance system could also help to improve institutional decision-making processes, which seem to be quite problematic in Malawian universities (Shawa, 2013).

\section{Conclusion}

In this paper, I started by providing the context and challenges faced by the university sector in Malawi in relation to a quality delivery of university education. Given the nature of the challenges, I have proposed four complementary ways for achieving quality university education. First, I have argued that there is a need for developing a coordinated higher education policy framework. This is important in order to have a higher education that talks to all necessary aspects from the national to institutional levels. Second, I have discussed a need to develop elaborate financing mechanisms arguing for four major aspects: a need for a procedural policy based financing mechanism to the university sector, a need to consider putting to a stop the practice of making state presidents automatic university chancellors to avoid a financing system that depends on the mercy of the presidency, a need to discerning a long-term realistic cost-sharing mechanism and a need for universities to increase their resource base. Third, I have suggested developing a robust quality assurance mechanism. Lastly I have posited developing a deliberative governance university system that could bring about democratic practices in the national as well institutional university governance system.

\section{References}

Bloom, D., Canning, D.,\& Chan, K. (2006). Higher education and economic development in Africa. Harvard University: Human Development Sector, Africa Region.

Brennan, J.,\& Shah, T. (2000). Managing quality in higher education: An International perspective on institutional assessment and change. Buckingham: OECD, SHRE and Open University Press.

Chimombo, J. P. A.(2003). Malawi: In P. Altbach D. Teffera(Eds). African higher education(pp.141-421). Bloomington and Indianapolis: Indiana University Press.

Dunga, S.H (2013). Financing higher education in Malawi: Prospects, challenges and opportunities. In D. Teferra (Ed). Funding higher education in sub-Saharan Africa (pp.184-.213). Hampshire. Palgrave MacMillan.

Elster, J. (1999). Introduction. In J. Elster (Ed.). Deliberative democracy(pp. 1-7). Cambridge: Cambridge University Press.

Green, D. (1994). (Ed.).What is quality in higher education?Bristol: SHREE \& Open University.

Gutmann, A.,\& Thompson, D. (2004). Why deliberative democracy. Princeton: PrincetonUniversity Press.

Hall, D.,\& Thomas, H. (2005).Links between higher education and employees in Malawi: The need for a dialogue. Journal of Higher Education Policy and Management, 27(1):67-69.

Harman, G. (1998). The management of quality assurance: A review of internationalpractice. Higher Education Quarterly, 52(4):345364.

Harvey, L.,\& Green, D. (1993). Defining quality. Assessment and Evaluation in Education, 18(1):9-34.

Hayward, M. F.,\& Ncayiyana, D. J. (2006). Report on the national education sector plan project: 30th October-18 November 2006. Lilongwe: Ministry of Education and Vocational Training (MoEVT).

Hayward, M.F. (2006). Quality assurance and accreditation of higher education in Africa. Paper presented at the Conference on Higher Education Reform in Francophone Africa: Understanding the Keys of Success: June 13-15, 2006. Ouagadougou:

Kerr, D., \& Mapanje, J. (2002). Academic freedom and the University of Malawi. African Studies Review, 45(2), 73-91.

Malawi Government. (2006a). National Education Sector Plan (NESP). Lilongwe: Ministry of Education and Vocational Training.

Malawi Government. (2006b). Malawi Growth and Development Strategy MGDS): 2006-2011. Lilongwe: Ministry of Economic Planning and Development.

Malawi Government. (2000a). Vision 2020: The national long-term development perspective for Malawi. Zomba: Malawi Central Africana Limited.

Malawi Government. (2000b). Policy and Investment Framework (PIF): 2000-2015. Lilongwe: Ministry of Education Science and Technology (MoEST).

Malawi Government. (2009). Malawi Education Country Status Report (CSR 2008/09). Lilongwe: Malawi Government.

Miller, D. (2000). Citizenship and national identity. Oxford: Polity Press.

Mzuzu University. (2005) Mzuzu Students' Handbook: 2005-2006. Mzuzu: MzuzuUniversity.

Sayed, Y., Mackenzie, I., Shall, A., \& Ward, J. (2008). Mainstreaming higher education in national and regional development in Southern Africa: A regional profile Southern African Regional Universities Association (SARUA).

Saint, W. S. (1992). Universities in Africa: Strategies for Stabilization and Revitalization. Washington, DC.: The World Bank Technical Paper Number 194, Africa Technical Department Series.

Shawa, L.B. (2007). Can higher education policy frameworks engender quality higher education in Malawian universities? Unpublished 
MEd thesis, Stellenbosch University: Stellenbosch.

Shawa, L.B. (2008). The Bologna process and the European gain: Africa's development demise? European Education, 40(1): 97-106.

Shawa, L.B. (2011). Exploring anti-democratic practices in university policy-steerage, management and governance in Malawi: a critical theory perspective. Unpublished PhD thesis, Victoria University of Wellington: Wellington.

Shawa, L.B. (2012). The big-man syndrome as a security threat in Malawi: A Critical theory perspective. Southern African Peace and Security Studies, 1(2): 44-56.

Shawa, L.B. (2013). Governance in Malawian Universities: The role of dialectical reasoning and communicative rationality. South African Journal of Higher Education, 27(1): 221-238.

South African Government. (2012). The higher education qualifications sub-framework. Pretoria: Ministry of Higher Education and Training.

University of Malawi Strategic Plan: 2012-2017. (2012). Zomba: University Office.

Vlasceanu, L. Grunberg L., \& Parlea, D. (2004). Quality assurance and accreditation: A glossary of basic terms and definitions.Bucharest: UNESCO-CEPES. Retrieved 21 March 2007 fromwww.cepes.ro/publications/default.htm

Vroeijenstijn, A. I. (1995). Improvement and accountability: Navigating between Scylla and Charybdis: Guide for external quality assessment in higher education.London: Jessica Kingsley Publishers. 